\title{
METÁFORAS DA CRISE: ENTRE O DISCURSO E A HIPERTEXTUALIDADE NO JORNALISMO ON-LINE
}

\author{
Emanuel Angelo Nascimento* \\ Universidade Estadual de Campinas \\ Instituto de Estudos da Linguagem \\ Campinas, SP, Brasil
}

\begin{abstract}
Resumo: Considerando a construção de sentidos e a materialidade hipertextual no jornalismo on-line, este artigo procura analisar, com base na Análise do Discurso (AD) de linha francesa, as condições de produção discursiva nos processos de enunciação digital em torno da crise econômica de 2008. Para tanto, analisa-se o contexto da "quebra" do banco Lehman Brothers, nos EUA, tematizada em diversas revistas, jornais e portais de notícias on-line de grande circulação no Brasil, tais como o Estadao.com.br, a Folha Online, a Globo.com, o Jornalnacional.globo.com, a ISTOÉ Dinheiro e a Veja.com que, à época, expressaram, através de uma rede de links hipertextuais, o temor dos mercados sobre uma possível recessão mundial. Observa-se, na análise, que as metáforas da crise presentes nos discursos político e econômico inserem-se no discurso das mídias por meio dos processos de entextualização discursiva e hipertextualização digital, com descolamentos e ressignificação dos sentidos que circulam socialmente.
\end{abstract}

Palavras-chave: Discurso. Mídia. Jornalismo on-line. Hipertextualidade. Crise.

\section{INTRODUÇÃO}

As relações entre discurso e enunciação e suas condições de produção e recepção, no contexto do avanço das tecnologias de informação e comunicação, passaram a ocupar novos campos de pesquisas de muitos linguistas e também de alguns analistas de discurso. Um olhar mais atento e minucioso sobre as transformações ocorridas principalmente nas áreas que lidam com a divulgação de notícias, de informação e de conhecimento te sido exigido de pesquisadores que se debruçam sobre as materialidades discursiva, textual e hipertextual que circulam na sociedade.

$\mathrm{O}$ crescente uso dessas tecnologias contribuiu significativamente para o surgimento de novos gêneros de discurso, principalmente no domínio da internet, através de novos suportes, como a "hipermídia" e o "hipertexto". Assim, o uso de computadores, celulares, câmeras tem provocado alterações nos modos de circulação tanto de informações, ideias, notícias e acontecimentos, possibilitando diferentes condições de produção textual e discursiva, e influenciando, desse modo, as relações entre tempo, espaço, sujeito, discurso e sociedade. Tal como destaca Maingueneau (2015, p. 39):

\footnotetext{
* Aluno especial do programa de pós-graduação em Linguística pelo Instituto de Estudos da Linguagem da Universidade Estadual de Campinas. E-mail: emanuellangelo@yahoo.com.br. São Paulo, SP, Brasil.
} 
[...] a materialidade do texto se tornou plural. Hoje, um pronunciamento político pode se manifestar ao mesmo tempo por uma forma impressa, por um enunciado em um site da Web, por uma gravação em áudio veiculada por uma rádio, por um vídeo em um site de compartilhamento, por um DVD... Sem falar das versões em número indeterminado que foram realizadas por câmeras ou gravações desse ou daquele espectador ou ouvinte.

Essa realidade permitiu, portanto, uma releitura das formas de interação verbal e não-verbal produzida pelos sujeitos, uma vez que, com o avanço das tecnologias, novas formas de linguagem e novas formas de discurso também surgiram, como, por exemplo, o discurso digital. Em termos de modos de significação e trabalho com o simbólico, Orlandi (2013) explica que o discurso digital ou o "discurso eletrônico", como a autora prefere chamar, associa-se a um "processo de significação que se movimenta o tempo todo em todos os lugares. Produzindo seus efeitos [...] que afetam os sujeitos aqui ou ali, por estas ou aquelas condições, nos gestos que se constituem no entremeio do real da língua e da história" (p. 17). Essas condições sócio-históricas possibilitadas pelas tecnologias, a exemplo do que afirma Dias (2012), instaura, assim, a urgência do dizer, por meio de reformulações da noção de sociedade e de espaços de enunciação.

Nesse sentido, procuramos compreender, com base na Análise do Discurso (AD), de linha francesa, a materialidade dessas transformações, no que diz respeito aos modos de circulação dos discursos e da construção de sentido no contexto da crise econômica mundial de 2008. Desse modo, o presente artigo busca estabelecer um diálogo entre diferentes perspectivas em AD, a partir de Pêcheux (1990 [1983]), Orlandi (2005, 2013), Charaudeau (2005) e Maingueneau (2006, 2015), além de mobilizar algumas das noções de hipertexto, no objetivo de compreender a circulação e a materialidade dos discursos em torno da crise de 2008, que teve uma cobertura bastante expressiva, principalmente no jornalismo on-line, através do hipertexto, de seus links e hiperlinks, possibilitando, como analisaremos, novas redefinições para o jornalismo tradicional, ao desafiar as limitações entre tempo e espaço, com correspondentes de notícia em diversos lugares do mundo e a qualquer momento, o que, a princípio, vai ao encontro das reflexões feitas por Maingueneau (2015).

\section{O JORNALISMO ON-LINE E O HIPERTEXTO}

O final do século XX assistiu a uma revolução nas tecnologias de comunicação e informação, levando à formação de meios de comunicação como instituições de alcance global nas áreas do jornalismo de informação em ciência, cultura, sociedade, economia, política e em outras áreas. A evolução do jornalismo on-line ${ }^{1}$, mais especificamente a evolução dos grandes veículos de comunicação jornalística na internet, está atrelada à história da rede mundial de computadores e às transformações advindas do uso das tecnologias. A internet, concebida como um ambiente de comunicação por excelência, tem modificado os modos de trabalho, nomeadamente a sua produção, ganhado uma importância exponencial em termos de difusão da informação e do conhecimento.

\footnotetext{
${ }^{1} \mathrm{O}$ jornalismo on-line também recebe denominações diversas, tais como webjornalismo, ciberjornalismo e jornalismo digital, cada qual com especificidades e características diferentes e sobre as quais não discorreremos neste artigo.
} 
Esse avanço tecnológico permitiu que nascessem novos paradigmas para o jornalismo, com a necessidade de publicação de textos on-line, viabilizando modos inovadores de textualização, como a "hipermídia", que permite integrar vídeo, som e imagem. Daí novos conceitos e recursos como (i) o "hipertexto"2 (com os hiperlinks que remetem para assuntos relacionados, que tornam possível um aprofundamento sobre determinada notícia ou uma ampliação dos sentidos em torno do texto de modo dinâmico, como veremos mais adiante); (ii) a "multimídia", que se relaciona com a escolha por parte do veículo acerca do formato mais adequado a cada notícia, com a convergência de diferentes tipos de mídia (hipermídia); (ii) a "interatividade", que permite a interação entre o jornal on-line e o hiperleitor, não mais passivo, que (a) seleciona os assuntos que mais lhe interessam, decidindo pelos caminhos sugeridos pelos hiperlinks; (b) participa e opina, deixando comentários; (c) compartilha textos e notícias com os demais hiperleitores, evidenciando a instantaneidade, a ubiquidade (a onipresença do estar aqui e além); havendo também (iv) a memória e o arquivo, que expandem os seus limites, com a atualização constante de informações/dados - o que causa um impacto na periodicidade e favorece o discurso eletrônico, ligado à rapidez de disponibilidade do material digital.

A dinâmica do jornalismo on-line, no contexto da velocidade ainda maior dos processos comunicativos, vai, desse modo, além do produto final acessível ao público. Do ponto de vista das agências de notícias, leva-se em conta a dimensão da competitividade, isto é, da necessidade de atender cada vez mais a públicos variados, e, em relação à própria notícia, atender à "corrida" pelo "furo de reportagem" e pelo ineditismo da informação. Trata-se, nesse sentido, de sair à frente com "jatos" de informação, com pequenas frases, trechos e resumos de notícia em destaque, e com atualização constante à medida que o fato acontece. A respeito desse imediatismo do jornalismo, por exemplo, o poeta mineiro Carlos Drummond de Andrade, em "Poema de Jornal", presente na obra Alguma Poesia (1930), reflete com genialidade, em seus versos, que:

O fato ainda não acabou de acontecer

e já a mão nervosa do repórter

o transforma em notícia

Assim, munido de celular e câmera digital, o repórter ou a equipe jornalística transforma $(\mathrm{m})$-se em uma unidade produtora de textos e imagens, de modo que o público tenha acesso não apenas ao cenário dos fatos, mas ao texto (com dados, números, detalhes, que de alguma forma tentam explicitar as informações). A internet, assim, vai além da TV, quando conjuga texto e imagem, transmissão ao vivo, on-line, com reportagem também impressa. E esse sincretismo (hibridismo) entre diversos suportes ganha cada vez mais espaço na tessitura do texto e na construção dos discursos, com a confluência entre a linguagem verbal e não verbal ocorrendo de forma híbrida e dinâmica.

\footnotetext{
${ }^{2}$ Consideramos aqui a noção de "hipertexto" desenvolvida por Theodor Holm Nelson, nos anos 60, em diálogo com outras perspectivas, conforme trataremos mais adiante nesta seção.
} 
Desse modo, na medida em que a internet se transforma em uma possante mídia, cresce também o interesse de pesquisadores em estudar as condições de produção do discurso jornalístico, sob o paradigma de ser um veículo que sintetiza todas as mídias, produzindo informações em "tempo real", em suporte eletrônico, com as vantagens visuais da TV, a mobilidade do rádio e o poder de documentação eletrônica, antes não proporcionados pelo impresso. Nesse sentido, vale destacar o que Pêcheux (1990 [1983]) afirma sobre essas condições de produção discursiva, uma vez que todo discurso depende "das redes de memória e dos trajetos sociais nos quais ele irrompe" (p. 56).

Justamente pensando nessa reflexão de Pêcheux, compreendemos que os discursos que circulam pelo jornalismo on-line se materializam em um contexto constituído uma linguagem e regras próprias. Afinal, o sincretismo entre diversos tipos de mídia demanda uma linguagem capaz de resumir as informações e prender a atenção do hiperleitor, principalmente ao conduzi-lo para links como "leia mais" e outros que propõem um resumo das notícias do dia ou da semana. Isto não significa esgotar o assunto, mas valerse de estratégias textuais e discursivas com apelo para recursos específicos que o suporte digital oferece a fim de manter o interesse do hiperleitor pelo assunto.

O portal do Estadão, na seção "Especial sobre a crise", por exemplo, apresentou ao hiperleitor, em 13/11/08, uma série de infográficos, um dos quais, inclusive, ilustra um dicionário interativo (cf. figura 1) sobre o tema da crise, apresentando para isso explicações de termos da economia.

\section{Figura 1 - Dicionário da crise}

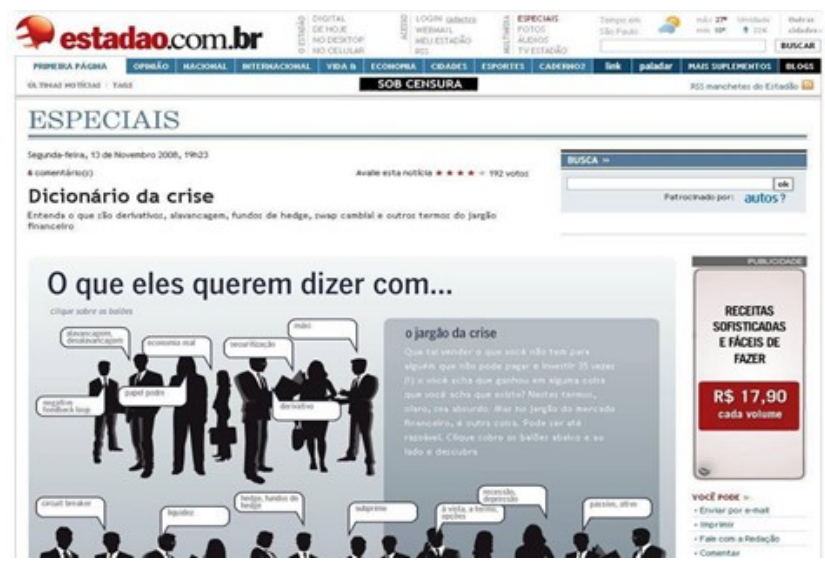

Fonte: Estadao.com.br, ESPECIAIS (13/11/08) atualizado às 19h23

Na página, intitulada "ESPECIAIS sobre a crise", o portal do Estadão simula, assim, vários personagens (executivos) conversando de pé em uma reunião, e ilustrando próximo a eles "balões de fala/diálogo". A cada click do hiperleitor sobre um balão específico, abre-se no quadro à direita da página a definição de termos tais como "recessão ou depressão", e também de diversos termos do inglês, tais como subprime, crash, entre outros, que possibilitam uma melhor compreensão de aspectos importantes sobre aquela crise. Sobre a palavra $\mathrm{crash}^{3}$, por exemplo, abre-se um quadro com a seguinte definição:

\footnotetext{
${ }^{3}$ Nota-se, na definição do termo crash, que o veículo jornalístico oferece ao leitor a explícita alusão à Crise de 1929, permitindo-lhe através da leitura estabelecer um possível paralelo entre a crise de 2008 e a de
} 
Crash é de causar arrepios. Remete ao histórico colapso da bolsa de Nova York de 1929, a que se seguiu a Grande Depressão ('ver depressão'), durante a qual 40\% dos bancos americanos faliram, o desemprego atingiu $25 \%$, as pessoas perderam seus depósitos, e as empresas, acesso ao crédito. À calamidade econômica, seguiu-se uma escalada totalitária que culminou na Segunda Guerra Mundial... (Estadao.com.br, 13/11/08).

Tanto do ponto de vista dos modos de enunciação por parte do veículo de imprensa quanto do ponto de vista da materialidade hipertextual e discursiva produzida no espaço da internet, observamos, a partir desse exemplo do "Dicionário da Crise", elaborado pelo portal Estadão, como o jornalismo on-line busca se destacar pela instantaneidade, pela interatividade, pela personalização e customização da informação, e pelo modo próprio e particular de enunciar o seu discurso.

\section{AS NOÇÕES DE HIPERTEXTO E O PAPEL DO HIPERLEITOR}

Narrativas hipertextuais existem muito antes de a tecnologia permitir a sua organização, como concebida hoje. Além disso, as mídias tradicionais sempre tiveram algum tipo de interatividade (nas seções de cartas de jornais e TVs, nos telefonemas para programas de rádio). No entanto, na organização viabilizada pela internet, o hipertexto "sugere" caminhos em formato e dinâmica diferentes, possibilitando ao hiperleitor o acesso a informações de maneira não hierárquica ${ }^{4}$, o que representa um processo digita; mais informatizado do que nas mídias de suporte impresso.

Abordaremos aqui algumas das diferentes noções de "hipertexto", já que dizem respeito a características específicas dos processos de enunciação digital.

Theodor Holm Nelson, pioneiro da Tecnologia da Informação, foi quem, na década de 1960, cunhou e utilizou pela primeira vez o termo 'hipertexto', partindo de conceitos importantes como strecht text (texto elástico), concebido como aquele que se "expande" e se "contrai". Associando, assim, a outros termos como "hipermídia", Nelson (1981) entende o "hipertexto" enquanto formas de escrita associadas, não sequenciais, que possibilitam conexões que podem ser seguidas em diferentes direções. $\mathrm{O}$ autor, ainda, reflete que a palavra 'hipertexto', geralmente, é utilizada para se referir a textos ramificados e responsivos, porém aponta que a palavra correspondente 'hipermídia' (que remete a gráficos e ramificações complexas, bem como a filmes e sons responsivos) é empregada com muito menos frequência. Em lugar dela utiliza-se a expressão 'multimídia interativa' (quatro sílabas mais longa), que, para Nelson (1981), não expressa a ideia de hipertexto.

Nesse entendimento, Dias (1999) faz um resgate histórico sobre a noção de "hipertexto", comentando que:

1929. Com isto, o portal Estadão evoca toda uma memória discursiva relacionada ao tema das grandes crises econômicas da história, importante para o aprofundamento e melhor compreensão sobre aquele assunto.

${ }^{4}$ Nesse caso, entenda-se "hierarquia" mais pelo processo pretendido desde a invenção da escrita e a intenção de se estabelecer uma ordem retilínea de escritura do que pela autonomia sempre presente pelo lado do leitor em estabelecer seu percurso autônomo diante do texto. 
[...] os primórdios do hipertexto podem ser associados a uma idéia de Agostino Ramelli cuja proposta era permitir a consulta simultânea de vários livros. A "roda de leitura" foi descrita na obra Le diverse et artificiose machine del Capitano Agostino Ramelli (Paris, 1588) (DIAS, 1999, p. 270).

A autora, além de citar o sonho da "roda de leitura", idealizada por Agostinho Ramelli como uma ferramenta de suporte hipertextual, relembra várias elementos que, ao longo do tempo, possibilitaram uma interação diferente entre o texto e o leitor. Dias (1999) cita, por exemplo, o sumário, os capítulos, os títulos, os resumos, os esquemas, os diagramas, os índices, as palavras-chave, as referências bibliográficas e os glossários. Com esses elementos "foi oferecida ao leitor a possibilidade de avaliar o conteúdo da obra de forma rápida e acessar partes do livro que mais lhe interessavam, de modo seletivo e não-linear.” Assim, Dias (1999) lembra que “[...] em 1965, Engelbart inventou o mouse e Theodor Nelson criou o termo "hipertexto" no seu projeto Xanadu, cuja proposta era implementar uma rede de publicações eletrônica, instantânea e universal".

Essa concepção de hipertexto associada a sistemas informatizados remete, por exemplo, ao que Orlandi (2013) vai chamar de "discurso eletrônico" e, por outro lado, ao que Lévy (1993) reflete, a respeito da rapidez com que o computador permite a pesquisa nos sumários, o uso dos instrumentos de localização e a passagem, nos termos do autor, "de um nó a outro". Pierre Lévy elenca, desse modo, seis princípios sobre os quais se assenta o hipertexto, sendo eles o(s):

1) Princípio de metamorfose: a rede hipertextual está em constante construção [...] 2) Princípio de heterogeneidade: os nós e as conexões de uma rede hipertextual são heterogêneos [...] 3) Principio de multiplicidade e de encaixe das escalas: o hipertexto se organiza em um modo "fractal" [...] 4) Princípio de exterioridade [...] seu crescimento e sua diminuição [...] dependem de um exterior indeterminado [...] 5) Princípio de topologia: nos hipertextos [...] o curso dos acontecimentos é uma questão de topologia, de caminhos [...] 6) Princípio de mobilidade dos centros: a rede não tem centro [...] trazendo ao redor de si uma ramificação infinita de pequenas raízes (LÉVY, 1993, p. 25-26).

Esses princípios dialogam com a noção concebida por Bairon (1995 apud KOCH, 2007 , p. 24), de que o hipertexto corresponde a "um texto estruturado em rede [...], uma matriz de textos potenciais, de forma que cada texto particular vai consistir em uma leitura realizada a partir dessa matriz”. Enquanto isso, para Xavier (2002, p. 29), o hipertexto é entendido como "um espaço virtual inédito e exclusivo no qual tem lugar um modo digital de enunciar e de construir sentido".

Essas noções de hipertexto, próximas entre si, pressupõem, por outro lado, a emergência da noção de hiperleitor e o papel que este assume nos processos de construção e atribuição de sentidos, como reflete Nonato:

[...] a co-autoria na hiperleitura assume um caráter ainda mais dramático dada a fractalidade do hipertexto: através de seus nós e links, o hipertexto se abre a infinitas trilhas possíveis. O hiperleitor terá que, além de significar o hipertexto, escolher que elos abrir e que elos descartar, enfim, terá que configurar seu próprio hipertexto, concretamente construir seu percurso (NONATO, 2006, p. 24). 
A natureza da hiperleitura e o papel do hiperleitor preexistem à Revolução da Informática, posto que, segundo as reflexões de Marcuschi (1999, p. 1), o hipertexto não é um novo paradigma de produção textual, mas, sendo nova a tecnologia, abrem-se caminhos para outras formas de textualidade, que permitem ao hiperleitor se deslocar de um lugar a outro por diversas vias de acesso (conceituais manipuláveis e dinâmicas) que se traduzem em um domínio de interações, reedições e constante atualização. Nesse sentido, a memória humana se estrutura de tal modo que "o homem compreende e retém melhor aquilo que está organizado em relação espacial, como é o caso das representações esquemáticas." (KOCH, 2007, p. 24).

Tendo em vista, portanto, essas concepções de hipertexto, no diálogo entre a perspectiva postulada por Ted Nelson e as demais aqui comentadas, seja a perspectiva da informática, seja a da Linguística Textual, podemos compreender, por exemplo, que durante a crise de 2008, esse modo hipertextual eletrônico permitiu que muitos hiperleitores enunciassem digitalmente sobre o assunto. Não raro, muitos deixaram comentários nos espaços abertos das notícias, participando de enquetes e/ou votações. No canto superior esquerdo da página do "dicionário interativo" do Estadão (figura 1), por exemplo, logo abaixo da data e horário de atualização daquela página, pode-seobservar a indicação de que seis (6) comentários de hiperleitores haviam já sido registrados sobre o tema da crise, e que 192 votos já haviam avaliado em uma escala de 1 a 5 estrelas a relevância da reportagem e do tema. Assim, tal como Koch (1997, p. 63) ressalta, o hipertexto é também "um suporte linguístico-semiótico" que faz do leitor/hiperleitor um coautor do texto e, ao mesmo tempo, permite que ele interaja e escolha os caminhos para desenvolver diferentes níveis de leitura e participação sobre determinado tema.

\section{CRISE, ENUNCIAÇÃO DIGITAL E AS METÁFORAS DO DISCURSO}

A forma de organização dos hiperlinks (no hipertexto) também revela outro aspecto importante da linguagem, que é a intencionalidade comunicativa e discursiva. Assim, cada veículo sugere, na tessitura dos hipertextos, alguns caminhos ao hiperleitor. Essas sugestões assumem um papel fundamental na construção do discurso das mídias digitais.

Da mesma forma, ocorre a partir da disponibilidade de recursos diversos no texto hipermidiático. Vídeos, áudios, imagens, infográficos, arquivos, reprodução de textos impressos, reprodução de capas das versões impressas das revistas, são todos recursos que exercem forte influência na construção dos modos de enunciação digital de cada jornal, de cada revista e de cada portal on-line.

Nesse sentido, é importante compreender as estratégias discursivas utilizadas pelo jornalismo on-line na construção de textos e discursos que visam provocar determinado(s) efeito(s) de sentido, principalmente com os recursos disponibilizados pelo ambiente digital - sobretudo, porque é através do hipertexto que se observa a grande velocidade e profusão das informações, e é por meio dele que os processos interativos e discursivos ocorrem de forma rápida e dinâmica em uma sociedade cada vez mais tecnológica e participativa. 
No contexto da cobertura da crise econômica mundial de 2008 realizada pela mídia brasileira, muitos jornais on-line e portais de notícia deram grande destaque à crise, de forma bastante expressiva e recorrente, fazendo circular pronunciamentos, discursos, enunciados em sua grande maioria em torno deste assunto. Grandes empresas de comunicações e jornalismo, inscritas em diferentes Formações Discursivas (FDs), se particularizam por nem sempre seguirem a mesma orientação em termos discursivos, contrapondo muitas vezes ideologias diferentes. Desempenham, dessa forma, um papel fundamental na atribuição de sentidos sobre a crise econômica. Além disso, a imagem destes veículos possui uma carga semântica importante, uma vez que tais veículos são também sinônimos de notícia e de jornalismo de grande circulação e abrangência nacional.

Nomes como Estadao.com.br, Folha Online, Veja.com, portal G1 e portal da Globo têm uma representatividade vinculada aos jornais impressos de circulação no Estado de São Paulo (nos dois primeiros casos). No terceiro caso, o da Veja, trata-se de uma revista de público geral e também de grande circulação no país; e, por último, o da rede de telecomunicações Globo caracteriza-se por sua abrangência nacional, com seus portais de notícia Globo.com e G1. Assim, nas páginas on-line desses veículos de notícia on-line, durante a coleta de dados e a constituição do corpus, pudemos identificar no topo de cada uma delas um logotipo específico (cf. figura 2), que remete ao veículo midiático digital.

Figura 2 - Logotipos de sites e portais de notícias (reprodução)

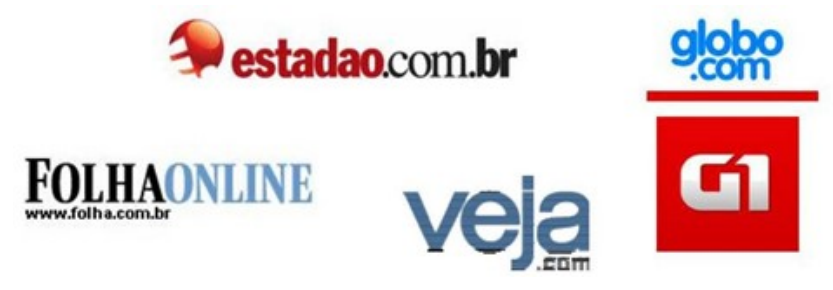

Assim, designações como “.com.br", "online," e “.com”, sendo sinônimos tanto de uma materialidade digital como representação de toda uma rede de informações de pronto acesso, permitem ao hiperleitor identificá-las enquanto logotipos oficiais das páginas do Estadão, da Folha Online, da Veja digital e dos portais de notícias da Globo. .

Este é um aspecto da tipologia hipertextual importante e que favorece a construção de sentidos produzidos por uma interdiscursividade que envolve, basicamente, dois signos - de um lado, as marcas Estadão, Folha, Veja e Globo expressam o que estas empresas de jornalismo simbolizam socialmente e historicamente; e, do outro, o ".com.br", o "online" e o ".com" são elementos que as situam no ciberespaço.

Pode-se criar, dessa forma, uma sensação de se estar diante de um material próprio de uma página na internet que reproduz digitalmente e complementa a materialidade e as informações dos jornais impressos, eventualmente semelhantes ou as mesmas das redes de telecomunicações (no caso do portal G1 e da Globo.com). Além de possuir credibilidade semelhante em relação às matérias jornalísticas tradicionais (impressas e televisivas), seja dos jornais, da revista e da tele-emissora, respectivamente, este material conta ainda com recursos tecnologicamente avançados que permitem outra dinâmica interativa. 
Nesse sentido, a relação do hiperleitor com o texto na internet tem uma opção também diferente através do hipertexto, uma vez que este formato de texto digital possui características diferentes dos demais tipos de texto, o que impõe, inclusive, uma diferente forma de construção da subjetividade. É fundamental ressaltar essa questão, pois, tal como afirma Lévy (1996), as linguagens e os sistemas de signos: “[...] induzem nossos funcionamentos intelectuais, e isso pode significar que não estamos passando ilesos às influências de toda essa nova hipertextualidade maquinodependente, criando um novo suporte para o desenvolvimento do raciocínio e da expressão que merece estudos e reflexão." (LÉVY,1996, p. 37).

A hipertextualidade faz surgir, desse modo, a constante possibilidade de reformulação por meio da reorganização feita pelo hiperleitor com a abertura de links e um diferente encadeamento da leitura. Essas mesmas possibilidades podem, no entanto, contribuir para o aumento da sensação de incompletude, visto que a presença dos links sugere uma "constante" abertura de páginas. Tem-se no hipertexto, de todo modo, um espaço vasto para observar os deslocamentos e as formulações de sentido, além da constituição de possíveis formas de textualidade, uma vez que diferentes modos de significação implicam diferentes tessituras enunciativas no ambiente digital. Nesse e em outros aspectos, o olhar da AD tem um papel importante, pois, como reflete Orlandi (2005, p. 15): “[...] a análise de discurso concebe a linguagem como mediação necessária entre o homem e a realidade natural e social. Essa mediação, que é o discurso, torna possível tanto a permanência e a continuidade quanto o deslocamento e a transformação do homem e da realidade em que ele vive.".

Nesse sentido, o esforço em compreender a materialidade hipertextual e discursiva no espaço digital representa, de certo modo, buscar explicitar o funcionamento e os modos de dizer do/no jornalismo on-line, tendo em vista os seus discursos e parâmetros próprios de enunciação digital. Em seus estudos sobre o hipertexto na sociedade de informação e sobre a constituição dos modos de enunciação digital, Xavier (2002) 5 afirma, dessa forma, que as novas tecnologias digitais de comunicação: “[...] estariam disponibilizando as condições sócio-técnicas para o surgimento de um novo modo de enunciação, que tem se evidenciado exponencialmente na chamada 'Sociedade da Informação', em plena Pós-Modernidade.” (XAVIER, 2002, p. 65)

$\mathrm{O}$ autor trata de questões importantes nos estudos sobre o hipertexto e sobre a enunciação digital, ressaltando algumas funções desempenhadas pelos hiperlinks no que diz respeito aos processos anafóricos, à referenciação, à remissão para textos externos e em relação aos elementos de coesão textual. Além disso, ao abordar as formas enunciativas verbais no tratamento do hipertexto como "texto eletrônico", Xavier (2002, p. 154) explica que essas mesmas formas verbais ganham um caráter singular na web, em especial por remeterem virtualmente seus leitores/usuários a outras formas verbais, a outros textos/discursos, além de conservar a remissão referencial que lhe é própria. Quanto a esses mecanismos de referenciação digital-remissiva, os hiperlinks, segundo o autor, apresentam pelo menos duas formas enunciativas: as enunciativas (i) verbais e (ii)

\footnotetext{
${ }^{5}$ Em tese de doutoramento intitulada "O hipertexto na sociedade de informação: a constituição do modo de enunciação digital", defendida na UNICAMP, em 2002, na área de Linguística.
} 
visuais, uma vez que "a tecnologia multimídia permite aos usuários comportarem na tela, simultaneamente, não só a escrita verbal, mas também efeitos sonoros e recursos visuais" (XAVIER, 2002, p. 156).

São justamente esses os aspectos que podemos identificar nos casos apresentados pelas mídias na cobertura on-line da crise econômica de 2008. Um especial "Lições de 29”, publicado em 24/11/08 pelo portal Estadão, disponibiliza, por exemplo, o vídeo de uma entrevista com o bibliófilo e ex-repórter do jornal O Estado de S. Paulo, José Ephim Mindlin. Nessa entrevista, disponível nas páginas do portal Estadão (cf. reprodução da página na figura 3), Mindlin fala sobre a crise de 29 e sobre o colapso da bolsa de Nova Iorque, naquela época apresentando sua experiência com aquela crise (em relatos e depoimentos pessoais), mas, desta vez, diante do cenário da crise econômica mundial de 2008 .

Figura 3 - Especial Lições de 29
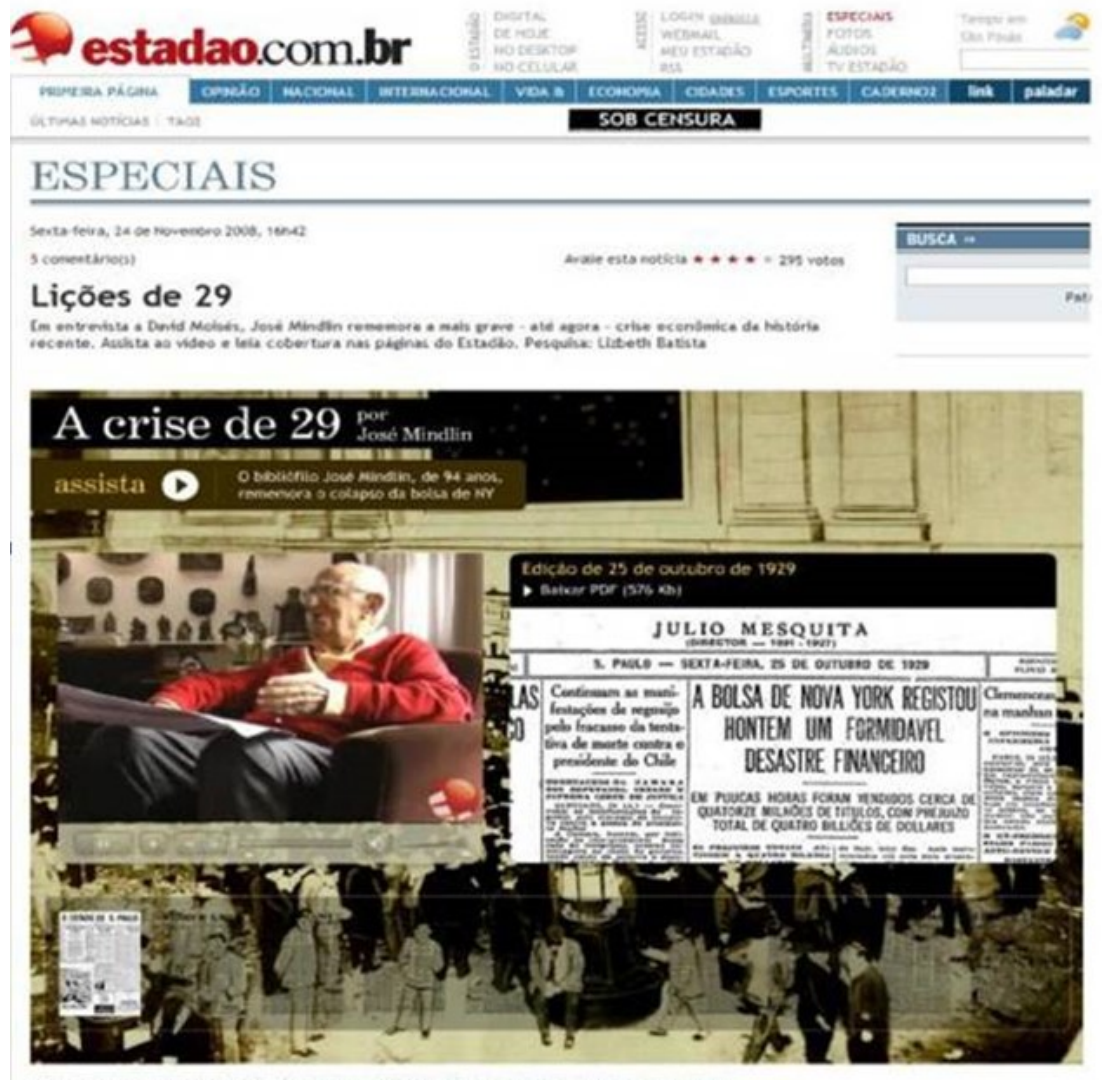

Fonte: Estadao.com.br, LIÇÕES DE 29 (24/11/08) atualizado às $16 \mathrm{~h} 42$

Além do vídeo, o especial do portal do Estadão disponibiliza, ainda, um texto de seu arquivo de memória, da edição de 25 de outubro de 1929, do jornal O Estado de S. Paulo, como é possível observar no quadro (em miniatura) à direita do vídeo (cf. figura 3). A manchete daquela edição do jornal impresso de 1929 noticiava, em português da época, uma matéria com o seguinte título em destaque na manchete: "A Bolsa de Nova York registrou hontem um formidável desastre financeiro". 
Desse modo, para além da análise dos recursos e estratégias enunciativas do discurso das mídias, que insere em seu discurso o discurso do outro (neste caso, como forma de citação de um argumento de autoridade, isto é, de quem viveu e passou pela experiência da Crise de 1929), observamos também os processos de enunciação digital do Estadão, que se vale dos recursos hipertextuais e hipermidiáticos (vídeo e arquivo digital) para construir, nos fios do dizer, o seu posicionamento sobre a crise de 2008.

Fica evidente, no modo de enunciar do portal Estadão, essa confluência hipermidiática entre texto e vídeo, oferecendo, a partir da interação entre o texto do jornal e o hiperleitor, um olhar a mais, resultante do diálogo entre entrevistador e entrevistado. Além da questão dos gêneros do discurso digital relacionados à cobertura da crise econômica, é possível observar, entre as diversas estratégias do jornalismo on-line, o uso frequente também das metáforas na construção de seu discurso como recurso linguísticosemântico que visa provocar determinados efeitos de sentido tanto em relação ao impacto da notícia quanto à construção hipermidiática dos acontecimentos discursivos6.

Em 16 de setembro de 2008, a Folha Online reproduziu, por exemplo, uma matéria da BBC Brasil, em sua página na internet (cf. figura 4), na qual podemos identificar o uso das metáforas da crise para construir a partir do discurso do outro (BBC Brasil) também o seu discurso (Folha Online). Naquele contexto, o sistema financeiro norte-americano enfrentava fortes dificuldades com a falência do banco Lehman Brothers, considerado até então o quarto maior banco de investimentos dos EUA, e que entrou com pedido de concordata, em 15/09/08, dia anterior à data da notícia da BBC Brasil, reproduzida pela Folha Online.

O risco que aquele evento representava para as economias globais é ilustrado no discurso do jornalismo on-line, que, através de metáforas ${ }^{7}$ como "queda das Bolsas", "quebra do banco", "crise atinge economia" e "agiu certo ao deixar afundar", revelam tanto o seu posicionamento a partir do discurso do pânico e do temor econômico como também o seu modo de enunciação nas trilhas do domínio digital. As metáforas direcionalmente orientadas "para baixo", como identificamos, expressam, por exemplo, o poder enunciativo que reforça o discurso do medo e do temor econômico, uma vez que "para baixo" representa um sema negativo.

Além disso, a Folha Online faz-se valer de algumas dessas metáforas, utilizandoas como links que remetem para outras matérias do mesmo portal. Esses modos de enunciar digitalmente visam oferecer ao hiperleitor uma contextualização da crise econômica, a partir de matérias já publicadas por aquele jornal on-line. E, nesse caso específico, busca sintetizar/resumir o contexto da falência do banco Lehman Brothers da mesma forma como ocorre com outros links que permitem, por exemplo, que o hiperleitor "entenda a crise financeira que atinge a economia dos EUA" (grifo nosso), tal como sugere este enunciado (lincado) na matéria (cf. figura 4) da página da Folha Online.

\footnotetext{
${ }^{6}$ Adotamos aqui o conceito de "acontecimento discursivo" postulado por Pêcheux (1990 [1983]), para quem a noção de acontecimento se situa na fronteira discursiva dos espaços da manipulação de significações estabilizadas e dos espaços de transformações do sentido.

${ }^{7} \mathrm{O}$ tratamento dado às metáforas, neste artigo, segue a mesma perspectiva postulada por Ullmann (1964), Ricoeur (1975) e Lakoff e Johnson (2002 [1980]).
} 
Figura 4 - Reprodução de notícia da BBC Brasil

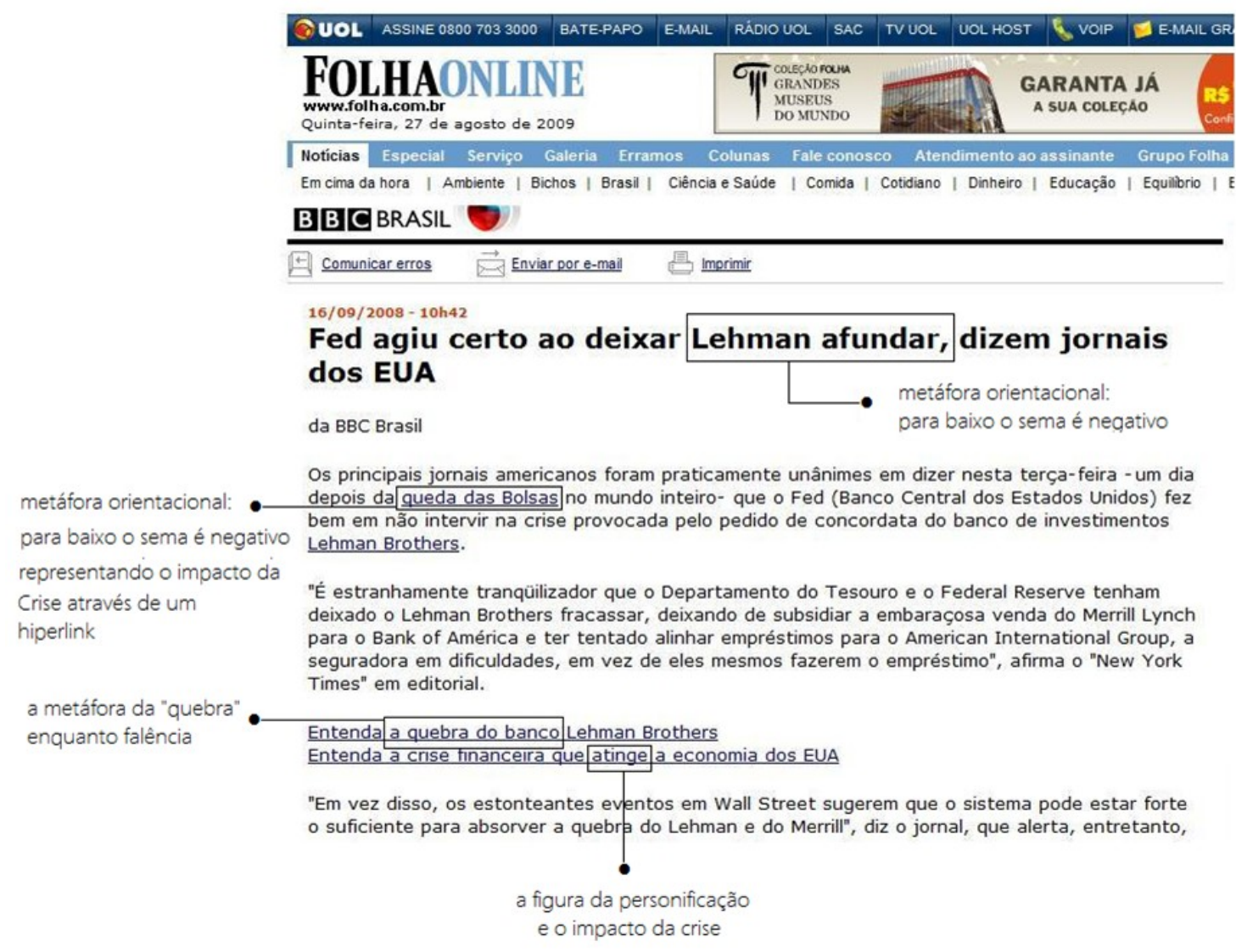

Figura 4. Fonte: Folha Online (16/09/08) atualizada às 10h42

Nessa mesma perspectiva, muitos outros jornais on-line, dentro daquele contexto de crise, adotaram essa mesma estratégia enunciativa hipertextual. E, do mesmo modo, fizeram das metáforas o lugar de representação de uma crise econômica que "assombrou" e "abalou" os mercados globais em diversos países. Não raro, encontramos larga ocorrência de alguns hiperlinks, como estes, a seguir, cujo núcleo semântico se apoia em metáforas e outras "figuras de linguagem" de sema fortemente negativo:

"Crise nos EUA volta a assombrar e Bovespa naufraga $4 \% "$

Estadao.com.br, Economia, 15/09/08

"Bovespa sucumbe à crise internacional e cai mais de 5\%"

Portal G1 da Globo, 15/09/08

"Crise quebra mais um banco americano"

Jornalnacional.com, 26/09/08

"Tóquio despenca: 9,38\%"

Veja.com.br, 08/10/08

"Crise financeira faz países voltarem a bater na porta do FMI"

Folha Online, 24/10/08

"Crise leva bancos médios da embriaguez à ressaca"

Folha Online, 29/07/09 
A crise econômica que abordamos neste trabalho teve como estopim a falência (quebra) do Banco Lehman Brothers, em 16 de setembro de 2008. A crise que se seguiu naquele período foi agravada com a falência também de diversas outras instituições financeiras nos EUA, como a AIG (American International Group). Além disso, grandes grupos como o Merrill Lynch e o Citigroup declararam perdas colossais em seus balanços em decorrência da crise. Diversos setores da indústria dos EUA e de outros países tiveram grandes prejuízos. No Brasil, as empresas Sadia, Aracruz Celulose e Votorantim anunciaram perdas bilionárias. Muitos setores do ramo automobilístico anunciaram demissões em massa e paralisação de sua produção. As principais bolsas de valores do mundo entraram em colapso, acumulando fortes quedas e perdas, desmoronando como um "castelo de cartas". Essa crise de 2008 se estendeu por 2009 e pelos anos seguintes, com consequências fortemente negativas em setores financeiros de diversos países.

O jornalismo on-line, nesse contexto, assumiu um papel particular na construção do discurso das mídias, na medida em que criou toda uma cena hipertextual e hipermidiática engendrada por uma multiplicidade de espaços enunciativos, potencializando, desse modo, o alcance da notícia sobre a crise de forma, até então, inédita. Na história das crises, provavelmente, essa tenha sido uma das primeiras acompanhada em tempo real pela internet e em escala planetária. Assim, as formas de enunciação, a arquitetura da notícia e a construção da informação midiática em torno da crise se materializaram a partir de estratégias discursivas específicas, como a eleição da crise, por exemplo, como um tema de destaque. Charaudeau, em O discurso das mídias (2005), ressalta, nesse sentido, que:

\footnotetext{
[...] os dados do contrato de comunicação midiática constituem o quadro de restrições no qual se desdobra a encenação do discurso de informação. Sob a batuta da dupla finalidade de credibilidade e de captação, as restrições relativas à posição das instâncias de comunicação e à captura do acontecimento dão instruções e impõem um modo de organização do discurso e um ordenamento temático (CHARAUDEAU, 2005, p. 129).
}

As estratégias de seleção dos fatos em torno da "crise econômica" representam, dessa forma, as escolhas efetuadas pela instância midiática sob um recorte social e histórico dos acontecimentos, obedecendo a certa hierarquia de importância orientada pela formação discursiva, pela formação ideológica e pelas formas de enunciação deste ou daquele veículo de notícia. A instância jornalística, nesse sentido, se encontra "ao mesmo tempo presa e livre na encenação de seu discurso, como um diretor na montagem de uma peça de teatro" (CHARAUDEAU, 2005, p. 129).

Igualmente, podemos compreender que a escolha desta ou daquela palavra como link para outra matéria, o uso intencional de metáforas de forte carga semântica com vistas a construir certos efeitos de sentido, a seleção de determinados enunciados (em destaque, lincados ou não) constituem as estratégias discursivas do jornalismo on-line e das mídias digitais - do mesmo modo que a seleção de um determinado título de uma notícia, as formas destacadas de algumas frases (proferidos seja por uma autoridade política, por um 
especialista em economia, por um ministro da Fazenda, etc.) atendem não apenas ao critério de informatividade e ineditismo da notícia, mas revelam também o seu posicionamento discursivo e ideológico, nos fios do dizer.

Assim, as mídias constroem o seu ethos discursivo, valendo-se dos recursos, por exemplo, de imagem, com a seleção deste ou daquele elemento nas capas das revistas, decisivos para a construção de determinada cenografia enunciativa com propósitos específicos - posto que "por meio do ethos discursivo, o destinatário está convocado a um lugar, inscrito na cena de enunciação que o texto implica" (MAINGUENEAU, 2006, p. 70).

Esta cenografia estabelece, portanto, as condições de enunciador e coenunciador, e também o espaço (topografia) e o tempo (cronografia) a partir dos quais a enunciação se desenvolve. É o que Maingueneau (2006) descreve, ao caracterizar um dos tipos de cena de enunciação, que é a cenografia, entendida, em suas próprias palavras, como: “[...] a cena de fala que o discurso pressupõe para poder ser enunciado e que, por sua vez, deve validar através de sua própria enunciação: qualquer discurso, por seu próprio desenvolvimento, pretende instituir a situação de enunciação que o torna pertinente." (MAINGUENEAU, 2006, p. 70).

Um exemplo já analisado, aqui neste artigo, é o do "Dicionário da Crise" (cf. figura 1), publicado, em 13/11/08, pelo portal Estadão, e que pretende simular diálogos entre executivos em uma reunião de negócios própria do ambiente empresarial e econômico, convocando o hiperleitor para que este possa compreender melhor os jargões específicos da área econômica no contexto da crise de 2008.

A partir desse e também de diversos outros casos, observamos, tal como explica Maingueneau (2015, p. 123), que a cenografia "se apoia na ideia de que o enunciador, por meio da enunciação, organiza a situação a partir da qual pretende enunciar". O "Dicionário da Crise" do Estadão mostra, desse modo, como essas estratégias funcionam na construção do discurso da mídia, uma vez que elas se ancoram em toda uma cena enunciativa, como em uma peça de teatro, permitindo dizer o que se tem a dizer sobre a crise.

Não raro, identificamos, a partir da análise dessas estratégias, traços do discurso publicitário presente no discurso das mídias, pois um dos objetivos pretendidos é o de aproximar e persuadir o enunciatário (no caso do discurso do jornalismo on-line, o leitor/internauta [hiperleitor]), articulando mecanismos enunciativos com apelo para imagens e cenas convidativas, no intuito de conquistar sua atenção.

Em outros portais de notícias que fizeram a cobertura da crise de 2008, encontramos fartos exemplos dessas estratégias discursivas que não apenas noticiam os fatos e os acontecimentos em torno da crise, mas que constroem todo um cenário, toda uma cenografia convocando o leitor a compreender os diversos contextos e aspectos da crise. Nesse sentido, as páginas on-line da revista Época, de 22/09/08 (cf. figuras 5, 6 e 7), apresentam junto às matérias daquela edição uma série de imagens que buscam de algum modo ilustrar o momento enfrentado por diversos países, setores e sujeitos envolvidos no contexto da crise. Em uma das matérias, disponibilizada na página digital, ilustra-se a foto de um homem de costas (cf. figura 5), durante o pregão da Bolsa da Malásia, levando as mãos à cabeça e expressando sua perplexidade diante da eclosão da crise. 
A capa da mesma revista, em versão digital (cf. figura 6), apresenta em destaque um questionamento sobre o contexto da crise, através do discurso do receio e do temor para um possível agravamento da situação econômica dos Estados Unidos. Para tanto, o veículo constrói uma cenografia, recorrendo a elementos que simbolizam metaforicamente a situação dos EUA (o chapéu do Tio Sam, quase submerso no oceano) no sentido de "estar afundando" junto do enunciado que questiona o contexto da crise: O pior já passou?

\begin{tabular}{|c|c|c|}
\hline $\begin{array}{l}\text { Figura } 5 \text { - Pregão na } \\
\text { Malásia }\end{array}$ & $\begin{array}{l}\text { Figura } 6 \text { - Imagem da capa } \\
\text { digital da revista }\end{array}$ & $\begin{array}{l}\text { Figura } 7 \text { - Operador em } \\
\text { Nova York }\end{array}$ \\
\hline 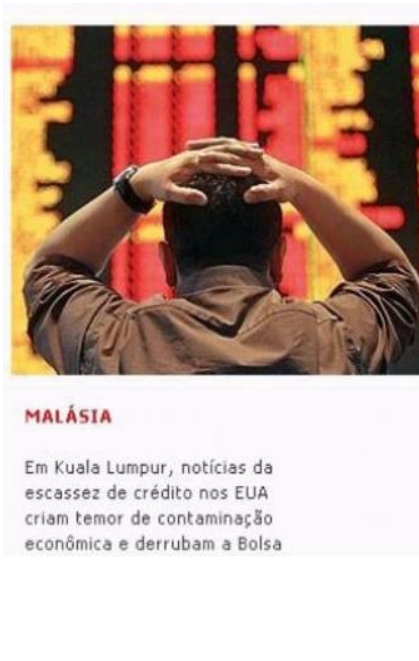 & 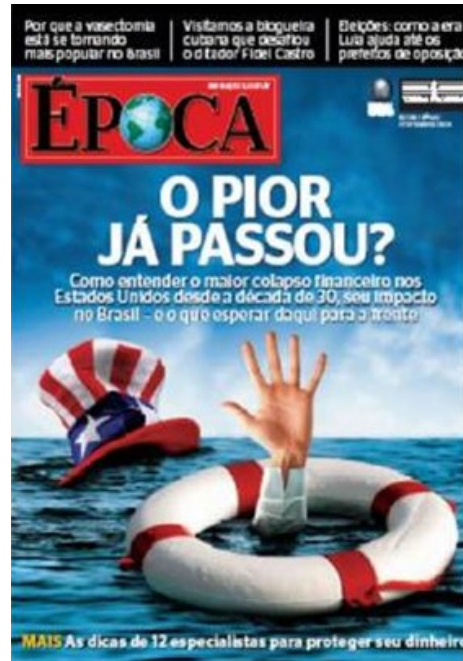 & 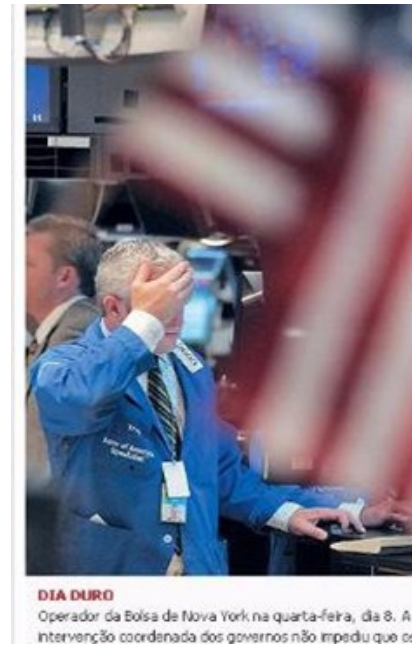 \\
\hline $\begin{array}{l}\text { Fonte: Foto on-line de Época de } \\
\text { 22/09/08 (reprodução) }\end{array}$ & $\begin{array}{l}\text { Fonte: Foto on-line de Época de } \\
\text { 22/09/08 (reprodução) }\end{array}$ & $\begin{array}{l}\text { Fonte: Foto on-line de Época de } \\
\text { 22/09/08 (reprodução) }\end{array}$ \\
\hline
\end{tabular}

Em outra matéria on-line, é ilustrada a imagem (cf. figura 7) de um operador da Bolsa de Nova Iorque vestido de uniforme azul, expressando a mesma perplexidade diante da crise. Observamos, ainda, que a metáfora visual utilizada, na capa da ÉPOCA (cf. figura 6), se aproxima daquela ilustrada pela revista ISTOÉ Dinheiro, em 24/08/08 (cf. figura 8).

A capa de ISTOÉ Dinheiro, a partir de uma cenografia enunciativa semelhante, parece estabelecer um diálogo intertextual com a capa da revista Época. Neste caso, selecionou também símbolos da cultura norte-americana (como a Estátua da Liberdade segurando uma placa de Wall Street por meio de uma corrente, e ao lado uma bandeira dos EUA), afundando em pleno oceano, sob o título "O fim de Wall Street". Assim, a revista ISTO É Dinheiro manifesta o mesmo discurso pessimista (daÉPOCA)em relação à economia dos EUA, ressaltando, além disso, o tom de crítica ao poderio econômico norteamericano, ao enunciar, na capa (junto à imagem), que "ninguém é tão grande que não possa quebrar". 
Figura 8 - Imagem da capa digital de ISTOÉ Dinheiro de 24/08/08 (reprodução)

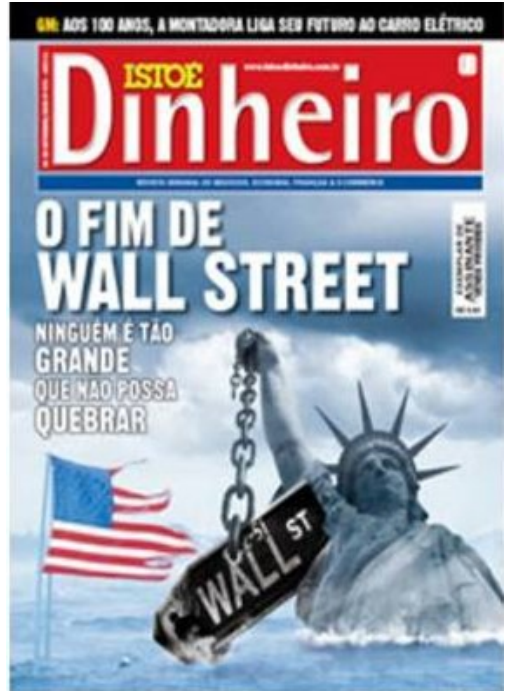

Fonte: ISTOÉ Dinheiro (24/08/08)

A escolha dessas cenografias, portanto, é plena de sentido. O discurso midiático, em suas formas de enunciar, mobiliza condições de produção e também visões de mundo cujas propriedades são tais que justificam o quadro da enunciação através de recursos verbais e não verbais. É o que podemos identificar também nas páginas on-line do jornal O Globo, de 16/09/08 (cf. figura 9), e de Veja.com, de 24/09/08 (cf. figura 10).

Analisando os enunciados em destaque em suas matérias - "Bolsas asiáticas têm forte queda sob o impacto do caso Lehman Brothers”, na página de O Globo (figura 9), e "Tempos de crise", na página da Veja (figura 10) -, é possível perceber o apelo às imagens, na medida em que esses discursos se apoiam em uma cenografia cuja semântica global é fortemente negativa, centralizando em sua base a ideia de "pânico e apreensão" nos mercados globais, diante do temor de uma possível recessão econômica no mundo. Os sujeitos ilustrados, desse modo, pelas páginas da Globo e da Veja, também levam as mãos à cabeça, expressando perplexidade e desespero, reforçando a semântica negativa.

Figura 9 - Imagem de notícia na página on-line do jornal 0 Globo

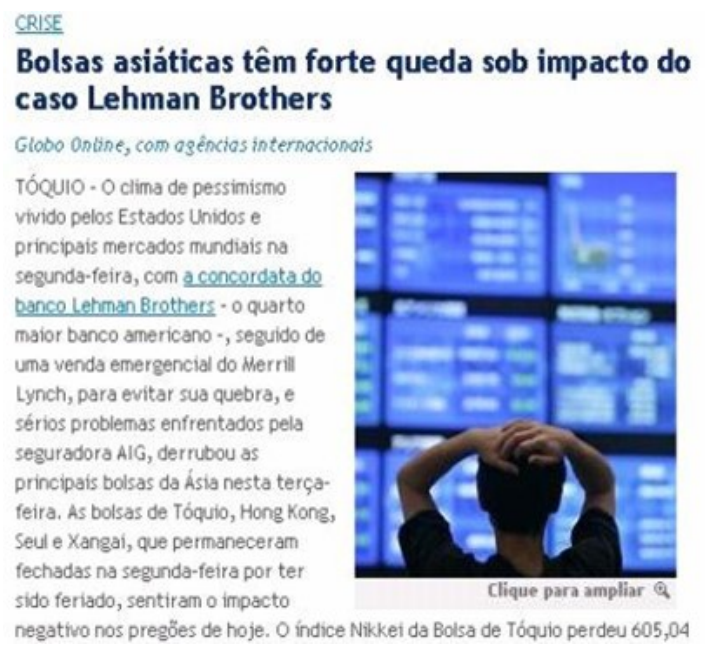

Fonte: Oglobo.globo.com (16/09/08) 
Figura 10 - Imagem de matéria na página on-line da Veja digital

candidatos à prefeitura do Rio de Janeiro e descubra qual deles tem a

opinião mais próxima da sua. Em www.veja.com.br/eleicoes

Tempos de crise

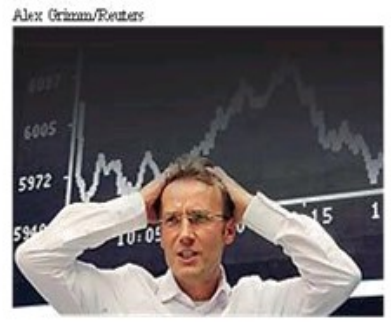

A semana que passou foi encarada por muitos especialistas como a pior desde o início da crise no mercado financeiro intemacional. A venda da Merrill Lynch, a quebra do Lehman Brothers - o quarto maior banco dos EUA - e o socorro de emergência à seguradora AIG foram alguns dos momentos mais drásticos desse processo. Entenda como tudo começou e quais foram as principais etapas até agora. Em Www.veja.com.br/cronologia

Fonte: Veja.com.br (24/09/08)

Nesse sentido, as estratégias discursivas de encenação da informação, no discurso das mídias, procedem a determinados modos de construção do acontecimento da crise, de acordo com os efeitos de sentido pretendidos. Para tanto, a reprodução de modos discursivos que estão circunscritos, por vezes, em uma mesma orientação ideológica ancora-se, não raro, em modos de descrever os acontecimentos, procurando provocar um efeito emocional suscetível de despertar naqueles que se informam instintos tais como os de insegurança, receio, desespero e medo. São estratégias comuns às quais recorrem, por exemplo, grupos de Formações Discursivas semelhantes ou próximos, que defendem a mesma ideia de que a crise econômica parece atingir a todos, indistintamente.

O retrato do pânico abordado pela câmera do jornalista deste ou daquele veículo, e reproduzido no espaço digital, parece estender-se a outros contextos da sociedade, evidenciando o impacto dos discursos midiáticos no espaço social. Entretanto, é preciso discernir a realidade como um todo de um real construído, pois "não há captura da realidade empírica que não passe pelo filtro de um ponto de vista particular, o qual constrói um objeto particular que é dado como um fragmento do real." (CHARAUDEAU, 2005, p. 131).

Afinal, são muitas as estratégias que recorrem à construção de cenografias enunciativas, como no caso da cobertura da crise econômica - estratégias estas que buscam construir a realidade através de um quadro discursivo, muitas vezes, alegórico, ficcional, fragmentado, sensacionalista, não correspondendo propriamente à realidade como um todo. Assim, essas mídias também digitais buscam flagrar o olhar do público por meio do apelo verbal e não-verbal, apresentando, ora ou outra, diálogos intertextuais e interdiscursivos, extraindo alguns sentidos de determinados contextos e os retextualizando em outros contextos. São exemplos as capas da Veja, de 24/09/08 (ver figura 11), e a capa da edição de ISTOÉ Dinheiro, de 29/10/08 (figura 12), em versões impressa e digital. 


\section{Figura 11 - Imagem da capa digital da Veja de $24 / 09 / 08$}

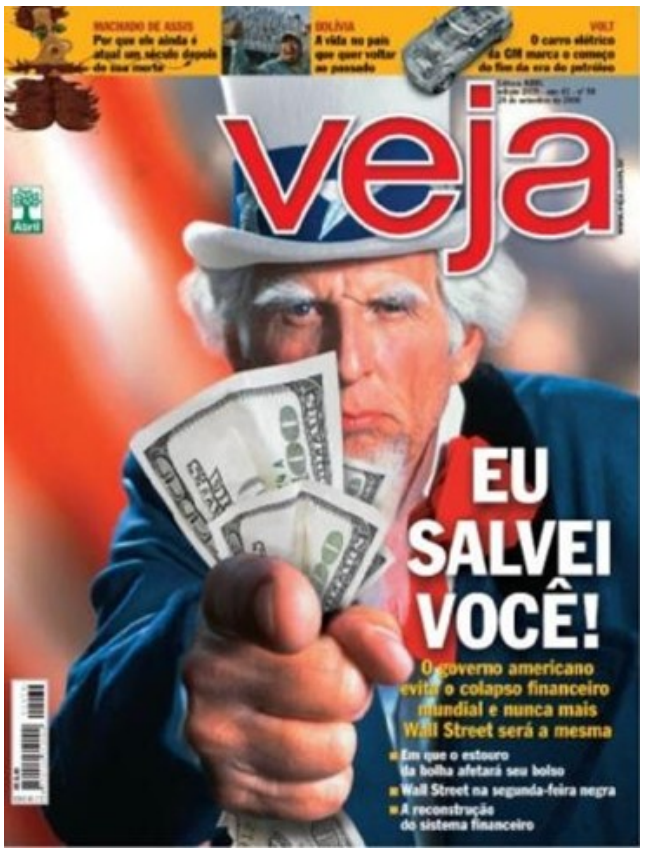

Fonte: Veja.com $(24 / 09 / 08)$
Figura 12 - Imagem da capa digital da ISTOÉ Dinheiro de 29/10/08

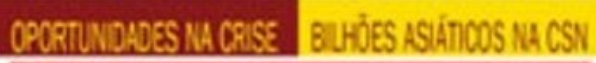
Dinheiro
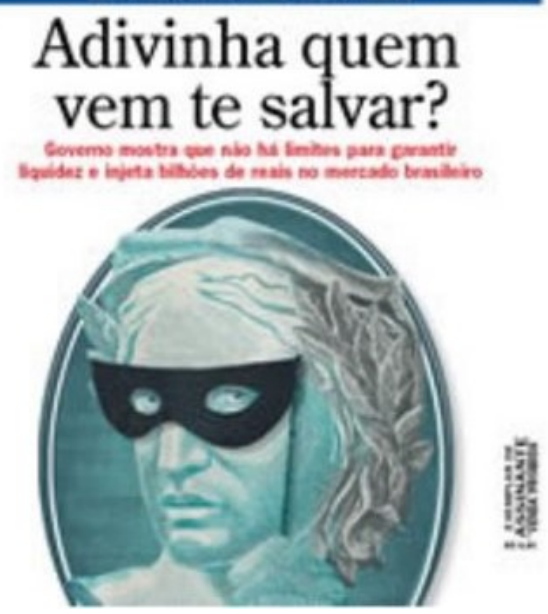

Fonte: ISTOÉ Dinheiro (29/10/08)

A capa da Veja (cf. figura 11) ilustra uma representação da imagem do Tio Sam olhando para o leitor, segurando em uma das mãos notas de dólar e, ao mesmo tempo, apontando com o dedo de frente para o leitor - ao lado do título principal da capa, expresso pelos enunciados "Eu salvei você!" (em destaque) e "O governo americano evita o colapso financeiro mundial e nunca mais Wall Street será a mesma". A leitura que se faz dessa cenografia é a de um discurso em favor do governo norte-americano e em favor da moeda norte-americana (o dólar). Esse mesmo discurso é defendido por meio de outra narrativa alegórica no lide da matéria principal da revista, em que aparece o título em destaque "A cavalaria salvou o dia", seguido de um enunciado resumindo, nos fios do discurso midiático, a ideia de que "O mundo parecia derreter na semana passada quando George W. Bush e seu secretário do Tesouro, Henry Paulson, comandaram a maior intervenção da história do capitalismo. Salvaram o dia, o sistema e nossos bolsos."(Veja, 24/09/08).

Em contrapartida, a capa da edição de ISTOÉ Dinheiro, de 29/10/08 (figura 12), publicada um mês depois desta edição da Veja, apresenta um discurso que refuta a ideia em favor da moeda norte-americana e, diferentemente, se apoia a favor da moeda brasileira (o real), em decorrência das medidas econômicas adotadas pelo governo brasileiro. Em destaque, tem-se o título "Adivinha quem vem te salvar?" e o enunciado "Governo mostra que não há limites para garantir liquidez e injeta bilhões de reais no mercado brasileiro".

Observamos, desse modo, que, nos rasgos da tessitura discursiva, é comum que uma revista cite o discurso da outra, repetindo a metáfora da salvação através da moeda, e não necessariamente cita esse discurso aceitando-o, pelo contrário: explicitando posicionamentos conflitantes, que se contrapõem - tal como explica Fiorin (1988), quando afirma que: 
Um discurso pode aceitar, implícita ou explicitamente, outro discurso, pode rejeitá-lo, pode repeti-lo num tom irônico ou irreverente. Por isso é que o discurso é o espaço da reprodução, do conflito ou da heterogeneidade. As relações interdiscursivas podem, assim, ser contratuais ou polêmicas (FIORIN, 1988, p. 45).

Aliás, essa reiteração da metáfora "a moeda é a salvação" ocorre por meio do processo de entextualização discursiva ${ }^{8}$, como pretendemos mostrar aqui, de acordo com os pressupostos de Bauman e Briggs (1990). Para isso, é preciso retomar o contexto do primeiro enunciado "Eu salvei você", da capa da revista Veja (cf. figura 11).

Ao se deparar com a quebra do banco Lehman Brother, que gerou um abalo no sistema financeiro norte-americano, o governo do então presidente dos EUA, George W. Bush, resolveu intervir na economia do país com um pacote de 700 bilhões de dólares para "socorrer" os bancos de um possível colapso. Nesse contexto imediato, a revista Veja explora em seu discurso a ideia de alívio com a metáfora "o dólar é a salvação". Entretanto, um mês depois de esse "socorro" bilionário do governo de Bush às instituições bancárias dos EUA não ter surtido grande efeito e nem ter impedido a quebradeira nas Bolsas ao redor do mundo, como efeito da crise norte-americana, a revista ISTOÉ Dinheiro, em sua capa (cf. figura 12), aproveita para extrair daquele contexto a metáfora "a moeda é a salvação", retextualizando-a em seu discurso. Ocorre que o contexto é diferente, pois o Brasil, até então, não havia sido afetado pela crise, provavelmente em razão de a moeda brasileira se apresentar bastante forte e a economia brasileira estável.

Neste caso, um discurso cita outro discurso contrapondo ideologias diferentes, mesmo que em momentos e condições de produção diferentes. Não necessariamente, os textos que os materializam remetem explicitamente um ao outro, mas deixam, na implicitude do dizer, visões de mundo que ora se aproximam, ora se distanciam. Isto é, crer que a moeda forte e estável de um determinado país pode ser a "proteção" e/ou a "salvação" para todo um sistema econômico local é adotar um posicionamento ideológico monetário nacionalista ou não. Posicionar-se em favor do dólar (diferentemente do discurso em favor do real) especifica ainda mais esse discurso e revela, por sua vez, uma posição ideológica que pode ser compreendida como neoliberalista, que acredita na soberania política e econômica dos EUA enquanto "potência" mundial. Em contrapartida, defender que o real se tornou uma moeda forte e estável frente ao dólar pode representar uma ideologia político-econômica nacionalista e protecionista que acredita na capacidade dos países emergentes de se impor em cenários de crise econômica internacional.

Tendo isso claro, procederemos à análise dos modos como essas relações interdiscursivas (conflitantes ou não) se estabelecem e como os discursos são construídos, levando em conta as condições de produção desses discursos, tais como os processos de entextualização discursiva, além dos deslocamento e ressignificação de determinados sentidos em diferentes contextos. Afinal, é o que parece ocorrer nos casos analisados a partir das figuras 11 e 12, em que os processos de metaforização e de entextualização discursiva são fundamentais na construção enunciativa.

\footnotetext{
${ }^{8}$ Para Bauman (2004), o conceito de "entextualização discursiva" pode ser traduzido como um processo de descontextualização e recontextualização, em que um discurso é retirado de um determinado contexto e colocado em outro.
} 
Esses mesmos processos de descontextualização e recontextualização discursiva aparecem diversas vezes no discurso jornalístico de outros veículos de notícia. Um caso bastante ilustrativo, ainda dentro daquele contexto mais abrangente, é o foco em torno do pacote de socorro do governo dos EUA totalizando 850 bilhões de dólares, com a redução de impostos estabelecida no projeto de socorrer as instituições financeiras daquele país. Alguns jornais on-line, como a Folha Online, repercutiram o fato algumas semanas depois, noticiando que nem mesmo o pacote de US\$ 850 bilhões conseguiu acalmar os investidores - como na matéria "Crise de confiança se sobrepõe a pacote dos EUA e arrasa mercados" (cf. figura 13), do dia 06/10/08.

O discurso cético adotado pela Folha Online é semelhante àquele presente na capa da revista ISTOÉ Dinheiro (cf. figura 14). Esta capa, no entanto, revela a uma estratégia discursiva diferente daquela matéria, ao se valer da ideia de "um pacote de US\$ 850 bilhões como salvação para a crise", retextualizando esse discurso a partir de uma cena enunciativa bastante irreverente e metafórica. A partir da figura ilustrativa, nota-se o apelo para a imagem de um "extintor" como instrumento de emergência, estampado com um adesivo amarelo em destaque indicando a inscrição "US\$ 850 bilhões" e logo abaixo o seguinte enunciado, que revela o discurso cético e questionador: "Isso apaga o incêndio?"

Figura 13 - Reprodução de matéria da Folha Online de 06/10/08
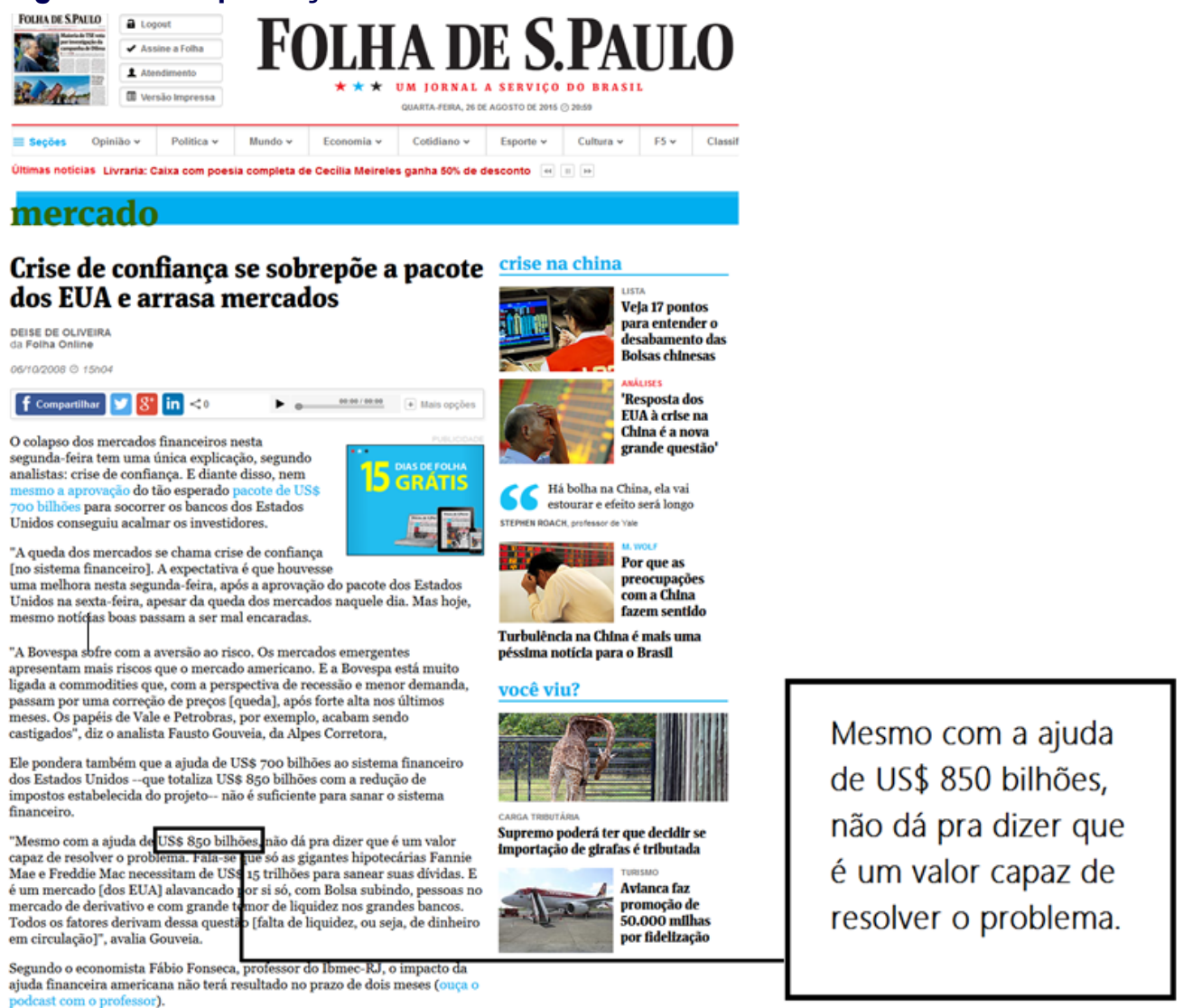

Fonte: Folha Online (06/10/08)

\footnotetext{
${ }^{9}$ Recorrendo aos recursos de hipermídia, a Folha Online disponibiliza o áudio dessa e de outras matérias, visando utilizar as tecnologias como forma de ampliar o alcance do público, como, por exemplo, o dos portadores de necessidades visuais, que teriam acesso a essa notícia, desse modo, através do áudio.
} 
Figura 14 - Reprodução da capa digital da ISTOÉ Dinheiro de 08/10/08

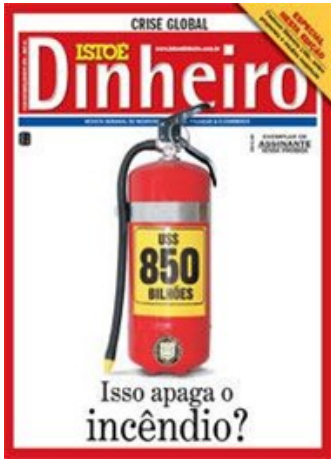

Fonte: ISTOÉ Dinheiro (08/10/08)

Outro exemplo, ainda, de entextualização discursiva que ocorre a partir do uso de uma linguagem metafórica e da construção de uma cenografia enunciativa que insere modos de enunciação de determinado contexto dentro de outro é o caso da crônica publicada no Caderno Metrópole, do jornal O Estado de S.Paulo, e também disponibilizada em sua página on-line no portal Estadão, no dia 16/09/08 (cf. figura 15).

Sob o título "Quebrou, brother?", o discurso jornalístico, utilizando-se de criatividade e estratégia comum àquelas também utilizadas pelo discurso do humor, não esconde o recurso da ironia com o intuito de explorar o contexto da "quebra" (falência) do banco Lehman Brothers e despertar a atenção do leitor, convidando-o à leitura do texto.

Figura 15 - Crônica na página do portal do Estadão

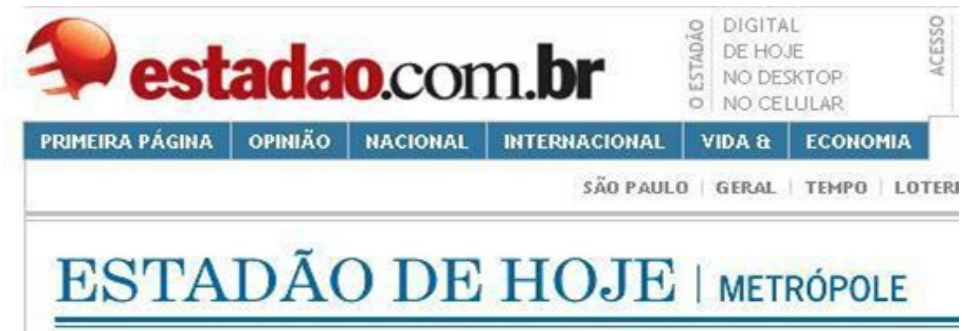

Terça-Feira, 16 de Setembro de 2008 | Versão Impressa

0 comentário(s)

\section{Quebrou, brother?}

A esta altura do colapso do sistema financeiro american Tamanho do texto? A A A A muito brasileiro endinheirado trazendo suas economias comecem a quebrar os bancos da Suiça, Ithas Jersey e C.

Bahamas. Liechtenstein... O Brasil. como se sabe. é o Daraíso dos bancos. Em r Fonte: Estadao.com.br (16/09/08)

Nota-se implícito, nos fios do dizer, o discurso velado, irônico, sobretudo, irreverente, que extrai da notícia sobre a falência do banco Lehman Brothers uma metáfora a partir da palavra "brother" (irmão, em inglês), estrategicamente. É nítido o deslocamento de sentido para o uso da linguagem coloquial do cotidiano das ruas, descontextualizando a quebra do Lehman Brothers nos EUA e a retextualizando, como podemos obsevar na narrativa: 
A esta altura do colapso do sistema financeiro americano, já deve ter muito brasileiro endinheirado trazendo suas economias de volta ao País. Antes que comecem a quebrar os bancos da Suíça, Ilhas Jersey e Cayman, Bahamas, Liechtenstein... O Brasil, como se sabe, é o paraíso dos bancos. Em nenhum outro lugar do mundo o setor bate recordes com a mesma frequência. Banqueiro ruim, por aqui, tem um em Bangu 8, no Rio, e outro no ostracismo, em São Paulo. Os demais não se queixam dos lucros exorbitantes do negócio [...] TÁ LIGADO? "Os brother tão tudo quebrando, mano!" - papo de periferia sobre o pedido de concordata do Lehman Brothers (Estadao.com.br, 16/09/08).

Esses são recursos que revelam (seja por meio da ironia, seja por meio do pânico ou medo) o tom dos discursos nos processos de enunciação e retextualização da crise nos fios do dizer, tendo em mente o que Discini (2003) afirma em relação ao discurso, posto que ele "vive também de ser e de fazer-ser, tudo sobremodalizado pelo parecer ou não parecer, no referido jogo da verdade compartilhado, de maneira cúmplice, pelo leitor." (p. 154).

\section{CONSIDERAÇÕES FINAIS}

Observamos, assim, ao cabo das reflexões propostas neste artigo, que as convergências dos modos de enunciação na esfera do jornalismo on-line e do hipertexto enquanto meio a partir do qual emergem condições de produção textual diferentes, estratégias discursivas que trilham caminhos diversos, modos de enunciação digital ancorados em links, hiperlinks e em recursos de hipermídia, explicitam, nesse sentido, as transformações ocorridas com o uso massivo das novas tecnologias de informação. Analisamos, portanto, como os mecanismos de linguagem no ambiente digital possibilitam diferentes formas de reorganização dos discursos e da vida social através da redistribuição de lugares de interpretação e autoria, além dos deslocamentos de sentido constantes, possibilitados pelo discurso digital ou "discurso eletrônico", como descreve Orlandi(2013).

$\mathrm{Na}$ configuração do hipertexto, identificamos a relação do hiperleitor com a interatividade e dinamicidade das informações, além das articulações entre os gêneros digitais e as condições de produção de sentido que colaboram para a construção do discurso das mídias. Nesse sentido, destacam-se as reflexões de Marcuschi (2004) de que:

\footnotetext{
[...] os gêneros caracterizam-se como eventos textuais altamente maleáveis, dinâmicos e plásticos. Surgem emparelhados a necessidades e atividade sócio- culturais, bem como na relação com inovações tecnológicas, o que é facilmente perceptível ao se considerar a quantidade de gêneros textuais hoje existentes em relação a sociedades anteriores à comunicação escrita. Os gêneros textuais surgem, situam-se e integram-se funcionalmente nas culturas em que se desenvolvem (MARCUSCHI, 2004, p. 19).
}

Os gêneros digitais, desse modo, autenticam o discurso eletrônico das mídias na medida em que apresentam características particulares e próprias da mediação estabelecida pela mídia digital. Assim, quando a Folha Online e/ou o portal do Estadão apresentam ao hiperleitor os seus infográficos e hiperlinks (como o 'Dicionário da Crise' e o 'Entenda a crise financeira que atinge a economia dos EUA'), que remetem para um aprofundamento da informação e da contextualização da crise de 2008 relacionados a eventos históricos relevantes, é possível compreender como o discurso das 
mídias se reveste de um modo particular de enunciar digitalmente, ancorado na hipertextualidade e na materialidade hipermidiática possibilitada pelas tecnologias. Nesse sentido, como lembra Pereira (2014): “[...] o vetor composição do gênero digital manifesta, em geral, tendência para oscilação ou existência simultânea [...] de um tempo e de um espaço mais apreensíveis como enunciados, mas fluidos, expansíveis dentro das possibilidades de enunciação abertas pelas tecnologias"(PEREIRA, 2014, p. 54).

Essa composição é materializada, portanto, na circulação de links e hiperlinks, na circulação hipermidiática de imagens, áudios, matérias e notícias, vídeos de entrevistas, que são produzidos ao mesmo tempo em que os acontecimentos discursivos e fatos em torno da crise econômica se difundem pelo espaço digital. Igualmente, a profusão de metáforas e imagens, os deslocamento de formas entextualizadas, a interdiscursividade na relação do dito anteriormente e alhures acessível pelos textos linkados se entrelaçam por meio de cenografias e modos de enunciação digital marcados, principalmente, pela heterogeneidade e pela interatividade próprias do discurso das mídias e do jornalismo online.

\section{REFERÊNCIAS}

ANDRADE, C. D. Poema de jornal. In: Alguma poesia (1930). 7. ed. Rio de Janeiro: Record, 2005.

BAIRON, S. Multimídia. São Paulo: Global, 1995.

BAUMAN, R. L. A world of others' words: cross-cultural perspectives on intertextuality. Oxford:WileyBlackwell, 2004.

; BRIGSS, C. L. Poetics and performance as critical perspectives on language and social life. Annual Review of Anthropology, v. 19, p. 59-88, 1990.

CHARAUDEAU, P. O discurso das mídias. São Paulo: Contexto, 2005.

DIAS, C. Hipertexto: evolução histórica e efeitos sociais. Ciência da Informação, v. 28, n.3, p. 267-275, 1999. Disponível em <http://revista.ibict.br/ciinf/article/view/830/862> Acesso em: 02 jun. 2016.

DIAS, C. Movimento da cibernética, saberes linguísticos e constituição do sujeito. In: FERREIRA, A. C. F.; MARTINS, R. (Org.). Linguagem e tecnologia. Campinas: Editora RG, 2012. p. 11-23.

DISCINI, N. O estilo nos textos. São Paulo: Contexto, 2003.

FIORIN, J. L. Linguagem e ideologia. São Paulo: Ática, 1988.

KOCH, I. V. O texto: construção de sentidos. São Paulo: Contexto, 1997.

Hipertexto e construção do sentido. Alfa, São Paulo, v. 51, n. 1, p. 23-38, 2007.

LAKOFF, G.; JOHNSON, M. Metáforas da vida cotidiana. Trad. Grupo da indeterminação e da metáfora. Campinas: Mercado de Letras; São Paulo: Educ, (2002 [1980]).

LÉVY, P. As tecnologias da inteligência: o futuro do pensamento na era da informática. Rio de Janeiro: Ed. 34, 1993.

O que é o virtual? São Paulo: Editora 34, 1996.

MAINGUENEAU, D. Discurso e análise do discurso. Trad. Sírio Possenti. São Paulo: Parábola Editorial,2015.

. Cenas da enunciação. Curitiba: Criar Edições, 2006.

MARCUSCHI, L. A. Gêneros textuais emergentes na tecnologia digital. In: MARCUSCHI, L. A.;

XAVIER, A. C. (Org.) Hipertexto e gêneros digitais. Rio Janeiro: Lucerna, 2004.

Linearização, cognição e referência: o desafio do hipertexto. Línguas e Instrumentos

Lingüisticos, Campinas, v. 3, p. 21-46, 1999.

NELSON, T. H. Literary machines. Sausalito (California): Mindful Press, 1981.

NONATO, E. R. S. A formação do hiperleitor: características do processo de desenvolvimento da autonomia e emancipação crítica do aluno-hiperleitor. 2006. Dissertação (Mestrado em Educação) Programa de Pós-graduação em Educação, Universidade do Estado da Bahia, Salvador, 2006.

ORLANDI, E. L. P. Análise de discurso: princípios e procedimentos. 6.ed.Campinas: Pontes, 2005. 
A materialidade do gesto de interpretação e o discurso eletrônico. In: DIAS, C. (Org.). Formas de mobilidade no espaço e-urbano: sentido e materialidade digital (online). Campinas: Labeurb/Nudecri, v. 2, p. 1-15, 2013.

PÊCHEUX, M. O discurso: estrutura ou acontecimento? Título original: Le discours : structure ou événement ? Campinas: Pontes, 1990 [1983].

PEREIRA, D. R. M. O estilo dos gêneros digitais. Estudos Semióticos [on-line], São Paulo, v. 10, n. 2, p. 53-65, dez. 2014. Disponível em <http://www.revistas.usp.br/esse/article/view/ 90146/92891> Acesso em: 26 ago. 2015.

RICOEUR, P. La métaphore vive. Paris: Seuil, 1975.

ULLMANN, S. Semântica: uma introdução à ciência do significado. Trad. J. A. Osório Mateus. 3. ed. Lisboa: Funadação Calouste Gulbenkian, 1964.

XAVIER, A. C. O hipertexto na sociedade de informação: a constituição do modo de enunciação digital. 2002. Tese (Doutorado em Linguística) - Programa de Pós-graduação em Linguística, Instituto de Estudos da Linguagem, Universidade Estadual de Campinas, Campinas, 2002.

Recebido em: 13/12/15. Aprovado em: 25/05/16.

Title: Economic crisis' metaphors: hypertextuality and discourse on on-line journalism Author: Emanuel Angelo Nascimento

Abstract: Considering the construction of meaning and the hypertextual materiality in online journalism, this article aims to analyze, based on the Discourse Analysis of the French orientation, the discursive production conditions throughout the processes of digital enunciation about the world economic crisis of 2008. In order to do that, we analyse the Lehman Brothers bank's crash in USA, which was thematized in several major on-line magazines, newspapers and news portals in Brazil, such as Estadao.com.br, Folha Online, Jornalnacional.globo.com, Globo.com, ISTOÉ Dinheiro and Veja.com, which expressed through a network of hypertextual links the fear of the markets about a possible global recession. It was observed in our analysis that the crisis metaphors present in the political and in the economic discourses are usually introduced into the media discourse by means of entextualization processes and digital hypertextualization with displacements of the ideas and meanings which circulate in the society.

Keywords: Discourse. Media. On-line journalism. Hypertextuality. Crisis.

Título: Metáforas de la crisis: entre el discurso y la hipertextualidad en el periodismo en línea

Autor: Emanuel Angelo Nascimento

Resumen: Considerando la construcción de sentidos y la materialidad hipertextual en el periodismo en línea, este artículo procura analizar, con base en el Análisis del Discurso (AD) de línea francesa, las condiciones de producción discursiva en los procesos de enunciación digital alrededor de la crisis económica de 2008. Para ello, se analiza el contexto de la ruina del banco Lehman Brothers, en los EUA, presentada en diversas revistas, periódicos y portadas de noticias el línea, de grande circulación en Brasil, tales como Estadao.com.br, Folha Online, Globo.com, Jornalnacional.globo.com, ISTOÉ Dinheiro y Veja.com que, à época, expresaron, por medio de una red de links hipertextuales, el temor de los mercados sobre una posible recesión mundial. Se observa, en el análisis, que las metáforas de la crisis presentes en los discursos político y económico se insieren en el discurso de las medias por medio de los procesos de entextualización discursiva y hipertextualización digital, con desplazamientos y re-significación de los sentidos que circulan socialmente.

Palabras-clave: Discurso. Media. Periodismo en línea. Hipertextualidad. Crisis.

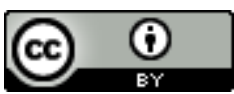

Este texto está licenciado com uma Licença Creative Commons Atribuição 4.0 Internacional. 